Managing moral reformation: the case of Queensland's reformatory for boys, 1871-1919

Clarissa Carden

Postdoctoral Research Fellow, Griffith Centre for Social and Cultural Research

Published in History of Education Review

doi.org/10.1108/HER-05-2020-0034 


\section{Managing moral reformation: the case of Queensland's reformatory for boys,}

\section{1-1919}

\section{Abstract}

\section{Purpose}

This article explores the case of the Queensland reformatory for boys through the years 1871-1919 to analyse how the institution negotiated the complex, and at times competing, goals of reforming, educating, and punishing its inmate population.

\section{Design/methodology/approach}

The article relies on documentary evidence, including archival material produced by the institution and newspaper records published between 1865, when the legislation allowing the institution to be created was passed, to 1919, when the institution ceased to be known as a 'reformatory.'

\section{Findings}

This research demonstrates that, despite considerable changes during the studied period, the overarching goal of reforming criminal and potentially-criminal young people continuously relied on achieving a balance between reformative techniques such as religious instruction and work placements, providing a useful education, and punishing offenders. It also demonstrates that, despite efforts to achieve this balance, the institution was often described as unsuccessful.

\section{Originality}

Due to the paucity of available archival evidence, there is still relatively little known about how the reformatories of late-nineteenth and early-twentieth-century Australia attempted to carry out programmes of moral reformation. This paper contributes to the field through an analysis of an institution which faced unusual challenges as a result of a complex inmate population.

Keywords: reformatory, Queensland, education, punishment, reformation, youth justice 


\section{Introduction}

In December 1880, Richard B, aged 15, was brought before the Bowen Circuit Court in Queensland, Australia, charged with the rape of a 12-year-old girl. In line with the law at the time, he received a death sentence. However, in recognition of his age, Richard B's sentence was commuted to three years' imprisonment in Queensland's reformatory school for boys (The Week, 1880, p. 8). He entered the institution on 5 January 1881 ("Queensland State Archives Item ID532416, Register admissions", 1871). The same year, David R, a child 'about ten years of age,' appeared before the Brisbane City Police Court, charged with being a neglected child. David R was sentenced to the reformatory school for seven years (Telegraph, 1881, p. 2). The length of the sentences handed down was based on age, rather than the seriousness of a child's offence. While boys could be released before the expiration of their sentence, the admissions register does not indicate that this was the case for David R ("Queensland State Archives Item ID532416, Register - admissions", 1871). While the record-keeping of the institution was never perfect it is possible, and indeed likely, that David R's period of incarceration was longer than Richard B's (e.g. "Report by the Public Service Inspector on the Westbrook Reformatory", 1906).

These sentences reveal something of the difficult task facing Queensland's reformatory school for boys. Reformatory schools, as they existed in Australia, Britain, and elsewhere, were created for the explicit purpose of housing children who had committed criminal offences (Dekker, 1990; Godfrey et al., 2017, p. 28). In Queensland, the government-run reformatory school for boys held both children convicted of criminal offences and those sentenced as neglected. This is one of the reasons that the landmark 1999 report of the Inquiry into Abuse of Children in Queensland Institutions (commonly known as the Forde report) memorably stated that 'many children who have been incarcerated in the State's reformatories, detention centres and similar institutions over the years should never have been incarcerated at all' (Commission of Inquiry into Abuse of Children in Queensland Institutions, 1999, p. ii).

\section{Blurred lines: offenders and non-offenders in the history of youth justice and welfare}

Historians of childhood provide important context for understanding the incarceration of youthful non-offenders. A partial explanation emerges from the work of Harry Hendrick who, writing in the British context, describes 'the narrative of victims/threats,' a phenomenon whereby children understood as victims of individuals or society were 'nearly always seen as harbouring the possibility of another condition, one that was sensed to be threatening' (Hendrick, 2005, p. 7). Boys sentenced to the reformatory school as 'neglected' existed in the type of liminal moral space Hendrick identifies. They were simultaneously victims, as implied by the legal term 'neglected,' and potential offenders in need of redirection. As Hendrick argues elsewhere, the nineteenth-century creation of the category of the juvenile delinquent rested on the assumption that if children were not raised and disciplined according to socially approved standards, the state would be required to take over the parental role. State intervention was viewed as necessary to correct deficits in the behaviours and personalities of 'young delinquents, and, by implication, all those neglected working-class children' (Hendrick, 2015, p. 37).

Stack $(1979,1994)$ describes the creation of a two-tier system, driven and supported by British reformers, whereby Hendrick's 'young delinquents' and 'neglected working-class children' were to be sent to two distinct types of institutions: reformatory and industrial schools. This British 
system was influential in Australia, as has been identified in studies of the systems in Victoria (Offer, 2018) and New South Wales (e.g. Quinn, 2002; Ramsland, 1982). Despite this influence, systems of welfare which incorporated institutionalisation have been implicated by David McCallum in unfairly criminalising Australian children $(2015,2017)$.

Research has been most advanced into the New South Wales system which evolved alongside, and had many similarities to, that which operated in Queensland (as described, for example, in Carden, 2019). In New South Wales, two pieces of legislation, passed on the same day, allowed industrial and reformatory schools to be created. The first institutions created under that legislation were industrial schools (Scrivener, 2000, p. 25). The lack of available reformatory schools led many young offenders to be charged with being neglected or with having 'no ostensible legal occupation' by magistrates who were eager to avoid sending juveniles to overcrowded adult prisons (Scrivener, 2000, p. 26). As a result, the first industrial school for boys, the nautical training ship Vernon, housed young offenders alongside the neglected children for whom it was intended. Gladys Scrivener writes of the Vernon that '[c]harges that the ship was being used as a reformatory' seemed to be generally 'accepted as facts but nobody, except the school superintendents, seemed to consider this a misuse' of the institution or of the legislation which created it (2000, p. 24).

This existing historiography demonstrates that the lack of division between offending and non-offending young people was not unique to Queensland, and is to some extent attributable to ideologies which were also present in Britain. It does not, however, adequately account for how the limited division between offending and non-offending young people impacted the missions and practices of early youth justice institutions. This article responds to this lacuna through an examination of how one institution, the reformatory school for boys in Queensland, negotiated interwoven goals of reforming, educating, and punishing young people in the context of a varied inmate population.

\section{Background and context}

Queensland's reformatory school was created in a context of increasing fear and concern around youth criminality. This was also a context in which there was a public appetite for welfare and youth justice institutions similar to those which were well-established in England. Reformatory and industrial schools in Queensland were initially conceptualised as part of a two-tier system. In this system, offending children, and those who were found to be neglected, would be housed in separate, albeit broadly similar, institutions. The institutions were expected to provide them with the skills and capabilities they needed to become productive citizens. This system of reformatory schools for criminal children and industrial schools for neglected children was envisioned as similar to that supported by humanitarian British reformers (as described in Stack, 1994).

In moving the second reading of the Bill which would become the Industrial and Reformatory Schools Act (1865), the colonial secretary noted that it had been adapted from bills in force in England. He also noted that it sought to address the fact that 'in the colony there were a large number of children unprotected and also children for whose education no provision had been made during their early age' (in Queensland Times, Ipswich Herald and General Advertiser, 1865a). Parliamentarians held out reformatory and industrial schools as a solution for these children. In debates on the Bill, a member of the legislative assembly, J. Bramston, reiterated parliament's intention that 'only neglected children were to be sent to an Industrial, and only convicted children 
to the Reformatory Schools' (in Brisbane Courier, 1865, p. 1). This intention did not last long after the institutions were created.

The Industrial and Reformatory Schools Act was passed in 1865. It was not until 1871 that the first boy was admitted to the first government-run reformatory school. No government-run industrial school for boys was ever constructed. As a result, the two-tier system promised by legislators was never put into practice in the Queensland context. Boys committed by the courts as neglected children were sentenced to the reformatory school in the absence of an industrial school. This was not an unusual state of affairs in Australia where, in the nineteenth century, children designated as neglected and those convicted of crimes were, despite efforts to the contrary, often kept together, with children in need of welfare thus criminalised (McCallum, 2015). The age of the incarcerated children changed between 1871 and 1919. The Industrial and Reformatory Schools Act (1865) initially encompassed young people under the age of fifteen (Queensland, 1865, sec. 5). In 1906, the legislation was altered to allow young people to be sentenced to industrial or reformatory schools up to the age of 17 (Queensland, 1906, sec. 4). This increased the possible pool of inmates for the institution.

From the outset, the practice of sentencing both 'neglected' and 'offending' children to the institution was well-established. Of the first 1000 admissions, which occurred between March 1871 and May 1900, 544 boys were sentenced as neglected, while 456 were sentenced for criminal offences. The mean age of all of the first 1000 boys sentenced to the institution was 11 , while the mean age of boys sentenced as neglected was slightly lower, at 10.59 ("Queensland State Archives Item ID532416, Register - admissions", 1871). Neglected children who found their way to the Queensland reformatory were predominantly charged as by police and sentenced by the courts. Some, like nine-year-old Thomas $M$ and 12-year-old John Nboth sentenced in 1876, were sentenced after being in an orphanage, highlighting a pathway through which already institutionalised boys could become incarcerated within the reformatory without committing criminal offences ("Queensland State Archives Item ID532416, Register - admissions", 1871).

As an institution which was required to act as what was, effectively, a welfare facility, as well as a youth justice institution, the reformatory often had conflicting purposes. It was faced with a varied inmate population with a broad range of educational and behavioural needs. The reformatory was charged with the care and reformation of these young people, and its staff were required to undertake that work in contexts which were not necessarily hospitable to welfare or care-work.

It is important to note that Australian reformatory schools were, despite their name, not necessarily related to departments of education or in any sense connected with formal schooling. In New South Wales, reformatories were operated at various times by the Department of Charitable Institutions, the State Children's Relief Department, and the Department of Public Instruction (Van Krieken, 1991). Only this last department was formally connected with the delivery of school-based education. In Queensland, the superintendents of the reformatory here under examination reported directly to the Colonial Secretary (later the Home Secretary), until 1911, when control was passed over to the State Children's Department (Find \& Connect, 2018). This is in contrast with the reformatory schools of Norway, for instance, which Thuen describes as a 'supplement to the school and as an alternative to the prison;' (1991, p. 52). There is no clear evidence of a trend, at least in Queensland, of incarcerating young people who misbehaved in ordinary schools in reformatory schools. However, the latter part of Thuen's description does stand - the reformatory school in Queensland was very much an alternative to the prison insofar as it provided courts with a means of punishing young offenders without putting them into contact with hardened adult criminals. 
However, as an alternative to prison for young offenders, it was also expected to serve as a deterrent for young people who were at risk of committing criminal actions.

While I refer to the reformatory school for boys as a single institution, it is important to note that, during its time as a reformatory (1871-1919), it underwent several changes in location and name. It began its life in 1871, as the reformatory for boys on the former prison hulk Proserpine, and ended its time as a youth justice facility in 1994, by which time it was known as the Westbrook Youth Detention Centre (Butterworth, 2014a).

Despite the changes which occurred in location and name over time, there was significant continuity in terms of staff, inmates, and how the institution was recognised during each of these transitions. It is, therefore, reasonable to describe this long history as the history of a single institution which took many forms over time. This article is concerned with the period between the years 1871-1919, during which it bore the name 'reformatory.' During these 48 years, the institution existed in four separate locations. In 1881 it moved from the Proserpine to a military encampment located at Signal Hill, Lytton. From there, it moved to a temporary site while preparations were made for its relocation to its final destination at Westbrook, around $130 \mathrm{~km}$ from Queensland's capital city of Brisbane, in 1900. These movements reflected both practical and ideological considerations and influenced how it was possible to enact modes of reformation, education, and punishment.

\section{Data and methodological considerations}

This article draws on a range of sources produced between the years 1865, when the legislation permitting for reformatory schools to be created was first passed in Queensland, and 1919 when the institution ceased to be referred to as a reformatory. It benefits, firstly, from archival sources, including the admission register for the institution for the years 1871-1900 and general correspondence relating to reformatory and industrial schools in Queensland between the years 1871-1919 (“Queensland State Archives Item ID532416, Register - admissions”, 1871).

This documentation, while useful, is limited. Research into institutions like the reformatory for boys can be hindered by a lack of access to official archival records. Various problems confront the historian seeking to understand this institution. The first is the reality that sensitive records are often sealed. In the case of the reformatory for boys in Queensland, records are generally sealed for 100 years. Even where this period has expired, additional problems - including incomplete or lost records - further hamper research. An additional limitation is the lack of access to the voices and experiences of the boys themselves. Recent scholarship has highlighted how historians of childhood have sought access to the voices of children, which, according to Musgrove et al., refers to 'what young people actually thought, felt and did rather than what they were expected or assumed to think, feel and do' (Musgrove et al., 2019, p. 12). Smith (2019) has demonstrated that it is possible to uncover something of children's voices from records which describe their actions. This approach is valuable, but is beyond the scope of the present project, with its focus on institutional practices. Instead, following Hendrick, I aim to 'provide readers with a text which, though written from "above" [that is, with a focus on policies and institutions], is overtly sympathetic to children (and young adolescents) and their perspectives' (2005, p. ix). 
Taking such an approach demands the recognition that, even where archival data is available, it must be treated with care. As Kaisa Vehkalahti has identified, archives of children's institutions are determined by 'choices made both in the past and in the present concerning documentation and filing,' which ought to prompt the historian to consider '[w]hy, and for what purposes,' particular documents have been created, saved, and archived, as well as how 'methods of documentation used by the original social workers and other officials in the past' have shaped the archives that are now available $(2016$, p. 434). In the present study, the practices of police, magistrates, and parents, as well as institution officials, have been influential in determining not only which children entered the reformatory, but also how they were categorised. Some previous scholars have identified that, in other Australian contexts, parents sometimes chose to have their children sentenced as 'neglected' rather than risk an offence against their names (van Krieken, 1986; Scrivener, 2000). In this way, parents altered the categorisation of their children and thus the composition of the archive. A child sentenced as 'neglected' may well have committed an offence. The category of child 'offenders' deserves equal suspicion. It is impossible to know for any certainty whether a judgement made about the guilt of any individual reformatory boy was fair and accurate. Even if boys convicted of offences were, indeed, guilty, the crimes of which they accused were most often very minor and the punishment often well beyond what would be considered acceptable by modern standards. A typical example is found in 11-year-old Robert W, sentenced to a year's incarceration in 1897, who was convicted of 'larceny' after allegedly stealing 'two hammers, one brace and bit, one plane, and a birdcage' with the aid of two other 'little boys' (Brisbane Courier, 1897, p. 3). The other 'little boys,' according to the Brisbane Courier, received a fine of 10 shillings or the alternative of eight days' imprisonment.

All of this highlights the significant limitations of archival research, particularly concerning the study of children who could not provide their own accounts to supplement and contest 'official narratives' (the power of which has been demonstrated by Sharma, 2010). While it is impossible to negate the biases in this record, additional context can be provided through the use of supplementary sources. To that end, the archival record is supplemented by the use of newspaper articles published in Queensland between the years 1865-1919, and particularly during the years 1871-1919, when the institution was in operation as a reformatory. In total, over 1500 newspaper articles have been sourced from the National Library of Australia's Trove. The items cited in this article are indicative of the broad themes emerging from this record and do not represent the entirety of the material examined. These newspaper sources provide evidence of the purported reasons for boys' incarceration as well as public perceptions of the institution. Newspaper articles, like other records, must be read critically. As Pegg, writing in the British context, has identified, the popular media of the nineteenth century often held up state interventions into the lives of offending and potentially offending young people as successful, lauding the attempt of the state to 'attempt to afford such children an opportunity to receive a moral and industrial education [and] divert these children from the influence of the streets, parental inattention and exposure to criminality' (Pegg, 2007, p. 434). A similar attitude is evident in the newspaper articles examined for this study, which tend to accept decisions made by the courts as legitimate and which rarely question the value of incarcerating young people. The analysis in this article, therefore, relies on a body of texts which tend to be favourable toward the reformatory.

The remainder of this article will draw on this evidence, flawed though it is, to develop an account of how Queensland's reformatory for boys managed the expectations that it would reform, educate, and, where necessary, punish a group of boys with diverse backgrounds and reasons for incarceration. It argues that the ideals of reformation and education, while imperfectly realised, were central to the institution's focus throughout the years 1871-1919, and were applied in ways 
which were influenced by both practical realities and prevailing ideologies around the treatment of offending and potentially-offending children. It further identifies punishment as undesirable, but essential to the institution's work.

\section{Reformation through faith and work}

Reformation was so central to the institution's purpose that it was embedded within its name. The point was reiterated in the preamble to the Industrial and Reformatory Schools Act, which refers to the expediency of not only providing 'for the care and custody of neglected and convicted children' but also to preventing 'the commission of crime by young persons' (Queensland, 1865). This positioned the institution as one which was successful insofar as it prevented crime through reforming both offending and neglected boys who, as Hendrick identified in the English context, were understood as potential offenders $(2005$, p. 7).

The government-run reformatory school engaged in a project of reformation which was, by its nature, ostensibly secular. This is unlike the British case. In Britain, reformatories and industrial schools were often run by private, philanthropic, religious groups (Cale, 1992; Hurt, 1984; Stack, $1979,1994)$. It is also in contrast with other institutions within Queensland itself. While the reformatory under examination was a secular institution, by 1910 it was one of only two government-run institutions which could house boys within the state's industrial and reformatory school system. The other was the Industrial School for Aboriginal Children located at Barambah, which held both boys and girls. While there was a short-lived government-run industrial school for girls, by 1910 the only industrial schools accepting girls in Queensland were operated by religious organisations.

However, there were several institutions to which 'neglected' children could be sentenced by 1910 . These were racially segregated. In 1910, the Queensland state government provided funding to support two Salvation Army industrial schools for white children, two Roman Catholic industrial schools for white children, and one Church of England industrial school for white children, alongside a Church of England industrial school for Aboriginal children and two Presbyterian industrial schools for Aboriginal children (Ryder, 1910, p. 2). While the state-run reformatory school for boys was not officially segregated by race, its early admissions were overwhelmingly white. This suggests a racialised attitude to the work of reforming children, whereby efforts to train children to be desirable citizens were influenced, to at least some extent, by the race of those children. As has been identified elsewhere, the late nineteenth to the early twentieth century was a time of racial anxiety in Queensland, with the education and training of white youth a focus of concern (Robinson and Wilson, 2008). The reformatory school existed within the context of this anxiety, and its whiteness may be understood as one of the mechanisms through which it sought to train young boys to become citizens (Carden, 2018a).

The predominance of religious institutions in the reformatory and industrial school space suggests that, for some Queenslanders, reformation was seen as something which could be best achieved through religious means. The period 1871-1919 was one in which the relationship between religion, the state, and children was particularly contested. This is perhaps best evidenced by the conflict over religious instruction in Queensland's public education system. From 1875 to 1910, public schools in Queensland were entirely secular. A series of debates both within and outside of parliament culminated in a 1910 referendum which passed, allowing for denominational religious instruction and 'non-sectarian' Bible reading in Queensland public schools (Carden, 2018b; Perkins, 2010). 
The reformatory, which provided education but which was not itself a public school, was never required to be wholly secular. The threat of sectarian tensions was therefore particularly pertinent to this institution, which held children regardless of religious denomination. The best available evidence of the institution's religious makeup comes from the register of admissions between 1871 and 1900. Of the first 1000 admissions, 346 were Catholic children, while 432 belonged to the Church of England. Of the remaining 222 admissions, 134 were of boys who were either Presbyterian, Wesleyan, or Lutheran ("Queensland State Archives Item ID532416, Register admissions", 1871). The inmates of the institution were therefore predominantly Christian, and a majority were Protestant. However, there was a sizeable Catholic minority. As an institution which was explicitly engaged in the work of moral reformation, the reformatory was required to tread a fine line. It had to allow the boys access to religious instruction and opportunities for worship, but it needed to do so in a way which did not threaten the rights of their families to determine their faith.

The available archival record provides a sense of how this was managed. In 1910, thensuperintendent Walter Richmond stated that ' $t$ t]he religious wants of the boys have been regularly attended to by the clergy of the several denominations' (Richmond, 1910). He also noted that he personally held non-denominational religious services on Sundays (Richmond, 1910). The reformatory, therefore, appears to have operated under the assumption that it was possible to engage in teaching and activities which were Christian, but not specific to a single denomination, and that such activities could and should operate alongside a programme of more specific denominational instruction.

Religion, however, was not and could not be the primary technique used to transform these boys, seen to be either actual or potential criminals, into useful and valuable citizens. The methods through which such reformation was to occur differed, with naval training favoured in the 1870 s and farm training preferred by the

early 1900s. One aspect of the reformatory system which remained constant throughout the studied period, and beyond, was the hiring-out system. The Queensland legislation provided for inmates to be placed in service with 'suitably licensed persons' for up to three years (Queensland, 1865 , sec. 8). In the boys' institution, at least, this was the desirable outcome of incarceration. Boys who had demonstrated a satisfactory level of behaviour while in the institution would be able to leave and enter the service of an employer -often, but not always, a farmer. The deal was seen as mutually beneficial - employers received cheap labour, while boys received an opportunity to learn an honest trade. Hiring out had the added benefit - for reformers - of removing boys from their habitual haunts.

The superintendent of the reformatory was responsible for reporting the immediate results of the institution's efforts, including the numbers of boys who had been 'hired out' and their behaviour while at work. For example, in 1910, a report to the Parliament of Queensland noted that thirty-three boys were at that time 'hired out' and that, on the whole, employers were satisfied with their work. At the time, seventy-six boys were in the institution. While some boys were returned to the institution as unsatisfactory, the Superintendent was 'of the opinion that the boys were not wholly to blame' in some cases (Richmond, 1910).

The practice of 'hiring out' boys was one of the most explicit ways in which the institution prepared inmates for a future as workers and citizens. However, 'hiring out' was a practice which was common across child welfare institutions in Australia and internationally (see for example Barbalet, 1983). In the context of the reformatory, it took on a different meaning. Orphanages and children's homes cared for young people who required support and were presumed harmless. The 
reformatory, on the other hand, was designed with the assumption that it would house young offenders who needed care, but who also posed a potential danger to the broader community. Reformation, in this case, included not only preparation for work but also a tailored education which took place within the institution itself. It also included a punitive regime which allowed the institution to serve as a deterrent for potential offenders.

\section{Education}

From 1871-1900, the reformatory's name bore the word 'school' (Butterworth, 2014b). After that time, despite its change of name, its regulations continued to refer to it as a 'reformatory school': a description which would continue for decades, long after the institution ceased to bear the name 'reformatory' in 1919 (as was noted in, for example, Schwarten, 1961). Education was vital to early justifications for creating a system of reformatory and industrial schools in Queensland. During the 1865 parliamentary debates over the legislation, the Colonial Secretary of the time argued that low attendance at the state's public schools showed the necessity of making attendance at reformatory and industrial schools compulsory (Queensland Times, Ipswich Herald and General Advertiser, 1865b). This is in keeping with the arguments of the British reformer Mary Carpenter, whose early campaigns for the creation of reformatory and industrial schools were influential in the Australian context. For Carpenter, reformatory and industrial schools were connected to, if distinct from, other means of providing education to disadvantaged children such as the ragged schooling movement (Carpenter, 1851).

Despite the connection between reformatory schools and day schools, the reformatory school was never run by the Department of Public Instruction. Indeed, initially, the education that did occur was of a haphazard and relatively informal manner. From 1871-1881, the reformatory was situated on the Proserpine, a disused ship. The cramped quarters limited the facilities available to the institution, even to the extent that, with no space for beds, boys were required to sleep on hammocks (Savige, 1993). In this context, where space was limited and the confines of the ship left no room for expansion, there could be no formal classroom. Despite this, boys were provided with a type of education. For the first few years of the institution's tenure on board the Proserpine, the school was run by the superintendent, James Wassell, an Inspector of the Water Police who had no teacher training (Savige, 1993). To supplement his lessons, Wassell arranged for trained music teachers to visit the institution and work with boys (Savige, 1993). From 1879, the classroom teaching in the institution became more professionalised with John Brown, a teacher under secondment from the Department of Public Instruction, taking on the role (Brown, 1879).

Brown continued with the institution when it moved to dry land at the military barracks at Lytton (Brown, 1881). Here, the education program continued with relatively little change in method and content. The musical instruction first instituted by Wassell, who remained as superintendent without his teaching responsibilities, continued. However, the movement to the military barracks allowed for physical expansion. This included the creation of a purpose-built classroom for the first time (Savige, 1993). From 1883, the instruction provided in the school was taken over by William Mahon, another instructor on secondment from the Department of Public Instruction, but one who had a reputation for ineffectual work and excessive drinking (Mahon, 1883; Savige, 1993).

These early educational experiences demonstrate the tensions at play in the provision of schooling in the reformatory context. As the name 'reformatory school,' in use from 1871-1900, indicates, education was one central purpose of the institution. However, the quality of the 
education available to inmates, and the venue in which that education was provided, varied dramatically.

While the education provided to boys was inconsistent, at least some early inmates likely received more formal schooling within the institution than they would have outside of it. In Queensland, the Education Act of 1875 technically made school compulsory for children between 6 and 12, but the 'compulsion clause' was not enacted until 1900. Even then, it was not until 1912 that students were required to attend school every day, rather than on half the days when school was open (Queensland, 1912, sec. 8). It was also in 1912 that children were required to attend school up to the age of fourteen.

By 1910, education was relatively formalised, with all boys under the age of fourteen attending school at the reformatory. Boys up to age twelve attended school for five hours per day, while those between the ages of twelve and fourteen attended for two and a half hours each day. In addition, boys attending the school spent two hours each night on preparation for their lessons (Ryder, 1910). Formal education was, by this point, a central function. (Carden, 2018a). This does not mean that the boys necessarily received a high standard of schooling. Van Krieken, writing about New South Wales child welfare institutions, suggests that 'it is likely that simply maintaining discipline took precedence over education' (1991, p. 45). This may have also been true of the Queensland reformatory.

The nature of the education provided changed over time. When the institution moved to its final site at Westbrook, in 1900, inmates were required to engage in hands-on agricultural education. The reformatory absorbed the state experimental farm. Much of the work required to operate the farm was completed by the boys. This was at times a source of tension. There are records of several complaints to, and investigations by, the Home Secretary's department in response to concerns that the Warder Gardener, responsible for teaching the boys how to work farmland, was ignoring Superintendent Richmond's authority in 1915 (Richmond, 1915). More importantly, it was a form of education which was seen as reformative to the character of young people.

\section{Punishment}

The reformatory school existed within a complex social context. Its preventative function, elucidated in the preamble to its governing legislation, was better served if it could also operate as a threat which could deter potential offenders (Queensland, 1865). It, therefore, had to appear to be punitive while nonetheless retaining its status as a more humane alternative to prisons. This tension between imperatives to punish and to reform was not unique to the Queensland context. For example, describing the decline of child imprisonment in mid-Victorian England, Stack (1994) notes that there were two distinct camps of campaigners for reformatory schools - hardliners and humanitarians. While the latter were opposed to all child imprisonment, the former, who believed that children convicted of crimes were culpable and should be punished, were not. He suggests that the humanitarian group had far more influence in reducing the numbers of children incarcerated in English prisons. Schroeder, describing the beliefs of influential English reformer Mary Carpenter, highlights the association between the desire to reform children and a view that they should not be punished (2008, p. 153).

This humanitarian view is evident in some of the surviving archival evidence. For example, in 1906, then-Superintendent Walter Richmond stated that ' $t$ t]he boys, however lawless and incorrigible they may have been in the outside world soon bow to the general air of orderliness and 
discipline existing here.' He stated that, for this reason, there was no need to inflict 'severe punishments' (Richmond, 1906, p. 7). There is not sufficient surviving evidence to evaluate the extent and nature of the punishments enacted by Richmond at the reformatory. However, his statement, made in a communication to a state government authority, may be taken as evidence of an environment in which 'good discipline' was desirable and separable from 'severe punishment.' Indeed, Richmond himself was forced into retirement in 1916 as a result of poor treatment of the boys, including a failure to provide adequate clean clothing, further demonstrating that ill-treatment was not within the allowable punitive boundaries of the institution (Carden, 2019, p. 368).

Whatever the reality of the punishment which occurred within the reformatory, the

Industrial and Reformatory Schools Act of 1865 struck a balance between the attitudes of what Stack (1994) describes as the hardliners and the humanitarians, allowing for children to be convicted to a reformatory school 'either in addition to or in lieu of such sentence as would but for this Act be passed as a punishment for the said offence' $(1865$, sec. 9). However, children who were incarcerated in prison could, upon the request of the visiting justice of the jail, be removed to a reformatory school $(1865$, sec. 10$)$. The effect of this legislation was, therefore, such that it did not prevent children from being incarcerated in adult jails, but allowed for such incarceration to be supplemented or replaced by a period in a reformatory school.

As a result, some of the earliest inmates of the reformatory school for boys were not sentenced to that institution at all. The institution's second inmate had initially been sentenced to three years penal servitude for cattle stealing, while two other early inmates had been sentenced to short periods of imprisonment for larceny ("Queensland State Archives Item ID532416, Register admissions", 1871). The admissions register does not record any inmates being transferred from other forms of imprisonment after 1872, suggesting that the practice was short-lived ("Queensland State Archives Item ID532416, Register - admissions", 1871).

By 1872 , then, the sentences of reformatory boys tended to be solely served within the institution. The reformatory itself came to be the primary tool wielded by courts to punish boys who they found to be deserving of imprisonment. This meant that boys who committed a broad range of offences including larceny, indecent assault, rape, bestiality, and mail robbery were all sent to the institution, where their sentences had an upper limit based on their age, rather than the severity of their offence (Queensland, 1865; "Queensland State Archives Item ID532416, Register - admissions", 1871).

The existence of the reformatory school disrupted the previous punitive regime within the Queensland context, at least insofar as it related to children. While reformatory schools were viewed as a gentler alternative to incarceration, they were still held out as a threat. In the Queensland record there are many instances of magistrates warning boys that, if they did not change their ways, they would be sentenced to spend time in the reformatory. In many cases, this threat was eventually carried out. The use of the institution as a threat indicates an understanding among magistrates that a sentence to a reformatory school was a form of punishment, entailing removal from friends, family, and well-known environments. Such an attitude was likely bolstered by a public discourse in which the presence of children sentenced as offenders within the reformatory was positioned as dangerous. This is perhaps best exemplified by a concern often expressed in letters-to-the-editor in response to particular cases where a child viewed as innocent was thrown in with 'the very worst vagabond children of this colony,' as one 1878 letter-writer put it (Comet, 1878, p. 3). The assumption that the reformatory was the site in which the 'very worst' boys were located may have worked alongside the reality of removal from familiar contexts to reinforce the idea that it 
operated as a punishment. This was bolstered by the reality that legal punishments also applied to anyone who might assist reformatory inmates in escaping, or to parents who did not pay courtmandated support to the institution. The punitive function of the reformatory, therefore, extended beyond inmates themselves and could encompass family members and loved ones.

\section{Conclusion}

While the scholarly literature provides an account of how lines between offending and nonoffending children came to be blurred, it has not, to date, clearly accounted for the impact of this 'blurring' on the mission and actions of affected institutions. This research has gone some way to identify how the reformatory school for boys, as an institution which experienced considerable overlap between offenders and non-offenders in its inmate population, sought to negotiate its ultimate aim of reformation alongside goals to educate and, where necessary, to punish.

It is difficult, if not impossible, to evaluate the success of the institution along any of the lines identified. The evidence suggests that, while the reformatory itself was a site of punishment, the sphere of the legitimate use of punishment within its boundaries was limited. Rather, it played a multifaceted role. The institution had to remain, in general, an undesirable place for boys to be sent. To this extent, it had to be seen to punish. However, as a welfare site, and a site in which moral reformation was the primary aim, there was always a risk of punishing too much, or, by failing to provide an adequate standard of living, inadvertently enacting punishments which were never intended by the government authorities who oversaw the institution's operation. These large-scale, unintentional, punitive actions, perceived to be caused by neglect, created a situation in which the Queensland Home Secretary, speaking just before Richmond's 1916 dismissal, remarked that: 'Westbrook is called a reformatory, but there is as much chance of reforming the inmates under existing conditions as there is of my developing wings' (Brisbane Courier, 1916, p. 6). A similar statement could easily have been made some decades later when, during the 1950s and 1960s, harsh and inventive physical punishments became an aspect of institutional life (Carden, 2018c).

This criticism highlights both the significance of reformation, as the overarching goal of the institution, to evaluations of its success. It also highlights an assumption that the legitimate mechanisms through which reformation can be carried out, including the mechanism of education, rely on a clean, wholesome environment. The fact that similar criticisms could have been applied at many periods during, and indeed at several periods after, 1871-1919 suggests that the conditions under which boys were intended to be reformed were often inadequate, unsuitable, and punitive.

But what of those loftier goals of reformation and education? How could they be measured? As has already been identified, the nature of the education received by reformatory boys shifted dramatically in accordance with factors including the practical constraints of the institution, the priorities of individual superintendents, broader legislative frameworks, and even the competence of specific teachers. There is some evidence to suggest that, during the institution's last years as a reformatory, when it came under the care of Superintendent Thomas Jones, the nature of the education provided to boys changed and expanded. One parliamentarian's humorous, but approving, account of the work done under Jones is recorded in Hansard:

He was pleased to say that the change in management was producing good results. He noticed, in reference to the institution, that they had debates. He would like to know whether the Minister [in charge of the institution - the Home Secretary] had any 
information of the result of the debates on some of the subjects. He noticed there were three or four interesting subjects, and the information might give hon. members a lead in the House (Roberts in Queensland Legislative Assembly, 1918, p. 2500)

While the statement was made in jest, it highlights an emerging form of education which was offered to boys outside of the classroom. Under Jones, practical forms of rural farming education were an essential part of the reformatory's programme. The inclusion of other types of educational work such as debate, and the continued provision of school for eligible boys, created a system in which at least some of the inmates had multiple types of learning open to them.

It is difficult to measure the extent to which the reformative goal of the institution was met. As Webber has ably shown in relation to the Refuge for the Destitute in London, scholars often focus on the journey of young people to a reformatory institution, and even their experiences within the institution, without adequately accounting for the post-institutional lives of former inmates (Webber, 2015). In the case of this Queensland institution, the lives of former inmates are difficult to chart. However, it has previously been established that desistance from offending over the lifecourse is the norm for juvenile offenders (Laub and Sampson, 2003, p. 91). The effect of any one institution, in this context, is not always possible to pin down.

Occasionally, former inmates appear in the court report pages of Queensland newspapers. One example is the case of a seventeen-year-old boy who had served three years in the reformatory, and who was sentenced to three months' imprisonment with hard labour in 1883 for stealing a parcel containing three shirts (Week, 1883, p. 11). In another case, a former inmate, aged 18, who had spent five years in the reformatory, was sentenced to one year's imprisonment with hard labour in 1902 for breaking and entering with the intention to commit a crime (Telegraph, 1902, p. 2). However, this kind of information does not account for the outcomes of all reformatory boys, nor does it provide evidence of their long-term outcomes. While it is beyond the scope of this study, an approach similar to that adopted by Godfrey et al (2017) in Young Criminal Lives, which provided whole-of-life accounts of young people leaving reformatory care in England, would be, perhaps, the only way to estimate the extent to which the reformatory prevented reoffending behaviours.

Certainly, from its earliest years, the reformatory was haunted by the suggestion that the combination of offending and non-offending children would prevent any efforts at reformation from being successful. In 1886, the attorney-general of Queensland, Charles Edward Chubb described both the perceived problem and the barrier to its resolution, succinctly, saying:

The reformatory at Lytton was very good in its way; but not only neglected but criminal children were received there and were associated together, and many of the latter, although young, were inured to criminal habits. It was not a good thing that children of vicious habits should be associated with simply neglected children; but, of course, separating them was a matter of expense (Chubb in Queensland Legislative Assembly, 1886, p. 1432)

That matter of expense was one which would remain unresolvable throughout the earliest years of the institution's history. Whether the lack of resolution should be taken as evidence that the blurring 
of the lines between offending and non-offending children became increasingly accepted as something which was not a barrier to reformation is questionable. Certainly, a lack of appetite for expenditure shaped the nature of the reformatory school and the types of practices in which it could engage.

While the reformatory sought, in varying ways, to meet the goals it had been set, its efforts were always shaped by financial constraints. Work, religious faith, and participation in the community through practices of hiring-out were inexpensive and could be seen as appropriate for all of the varied boys within the institution. The same can be said of education, both scholarly and practical and nature. The types of techniques which were applied to the boys in the reformatory, then, were shaped by money (or its lack) as much as by the actual goals of the institutions or the diversity of its inmate population. 


\section{References}

Barbalet, M. (1983), Far from a Low Gutter Girl: The Forgotten World of State Wards, South Australia, 1887-1940, Oxford University Press, Melbourne ; New York.

Brisbane Courier. (1865), "Parliament. Legislative Council. Wednesday, July 12", Brisbane, 13 July, p. 1.

Brisbane Courier. (1897), “Accidents and Offences", Brisbane, 25 February, p. 3.

Brisbane Courier. (1916), "Westbrook Reformatory. Mr. Huxham's visit. Radical reforms to be instituted.", Brisbane, 18 July, p. 6.

Brown, J. (1879), "Annual Return of the Reformatory Hulk School for the year 1879".

Brown, J. (1881), "Annual Return of the Lytton Reformatory School for the Year 1881".

Butterworth, L. (2014a), "Reformatory School for Boys - Hulk Proserpine - Organisation - Find \& Connect - Queensland", Document, , available at: https://www.findandconnect.gov.au/ref/qld/biogs/QE00529b.htm\#related (accessed 25 August 2017).

Butterworth, L. (2014b), “Diamantina Reformatory School for Boys - Organisation - Find \& Connect Queensland", Find \& Connect, Document, , available at: https://www.findandconnect.gov.au/ref/qld/biogs/QE00532b.htm\#related (accessed 26 March 2019).

Cale, M. (1992), "Working for God? Staffing the Victorian reformatory and industrial school system", History of Education, Vol. 21 No. 2, pp. 113-127.

Carden, C. (2018a), "Reformatory schools and Whiteness in danger: An Australian case", Childhood, pp. 1-11.

Carden, C. (2018b), "Bibles in state schools: Moral formation in the late nineteenth and early twentieth century Queensland school", History of Education Review, Vol. 47 No. 1.

Carden, C. (2018c), "A breakdown of reformatory education: Remembering Westbrook", History of Education Review, Vol. 47 No. 1.

Carden, C. (2019), "From Reformatory to Farm Home: Developments in Twentieth-Century Juvenile Justice", Cultural and Social History, Vol. 16 No. 3, pp. 359-374.

Carpenter, M. (1851), Reformatory Schools for the Children of the Perishing and Dangerous Classes, and for Juvenile Offenders, C. Gilpin, 5, Bishipsgate Street Without, London.

Comet. (1878), “Correspondence”, Morning Bulletin, Rockhampton, 8 August, p. 3.

Commission of Inquiry into Abuse of Children in Queensland Institutions. (1999), Report of the Commission of Inquiry into Abuse of Children in Queensland Institutions, Queensland Government, Brisbane.

Dekker, J.J. (1990), "The Role of Temporary Marginalization. Reformatories and Insane Asylums: The Netherlands in the Nineteenth Century", Peadegogica Historica, Vol. 26 No. 2, pp. 125-146. 
Find \& Connect. (2018), "Westbrook Reformatory for Boys", available at: https://www.findandconnect.gov.au/guide/qld/QE00046 (accessed 1 April 2019).

Godfrey, B.S., Shore, H., Cox, P. and Alker, Z. (2017), Young Criminal Lives: Life Courses and Life Chances from 1850, Oxford University Press, Oxford, United Kingdom.

Goffman, E. (1975), Asylums, Penguin Books, Middlesex, England.

Hendrick, H. (2005), Child Welfare: England 1872-1989., Routledge, London, available at: http://public.ebookcentral.proquest.com/choice/publicfullrecord.aspx?p=179042 (accessed 11 August 2020).

Hendrick, H. (2015), "Constructions and reconstructions of British childhood: an interpretive survey, 1800 to the present", in James, A. and Prout, A. (Eds.), Constructing and Reconstructing Childhood: Contemporary Issues in the Sociological Study of Childhood, Routledge, New York, pp. 29-53.

Hurt, J. (1984), "Reformatory and industrial schools before 1933", History of Education, Vol. 13 No. 1, pp. 45-58.

van Krieken, R. (1986), "Social Theory and Child Welfare: Beyond Social Control", Theory and Society, Vol. 15 No. 3, pp. 401-429.

Laub, J.H. and Sampson, R.J. (2003), Shared Beginnings, Divergent Lives: Delinquent Boys to Age 70, Harvard University Press, Cambridge, Mass.

Mahon, W. (1883), "Annual Return of the Lytton Reformatory School for the Year 1881".

McCallum, D. (2015), "Unstable categories: children in welfare and justice", Griffith Law Review, Vol. 24 No. 2, pp. 181-198.

McCallum, D. (2017), Criminalizing Children: Welfare and the State in Australia, 1st ed., Cambridge University Press, Cambridge, available at:https://doi.org/10.1017/9781316535028.

Musgrove, N., Pascoe Leahy, C. and Moruzi, K. (2019), "Hearing Children's Voices: Conceptual and Methodological Challenges", in Moruzi, K., Musgrove, N. and Pascoe Leahy, C. (Eds.), Children's Voices from the Past, Springer International Publishing, Cham, pp. 1-25.

Offer, E. (2018), "Police Use or Misuse? Police Agency and 'The Neglected and Criminal Children's Act 1864'”, Victorian Historical Journal, Vol. 89 No. 1, pp. 27-43.

Pegg, S. (2007), "Juvenile Criminality And Semi-Criminality: Learning From Victorian Perceptions And Responses", Liverpool Law Review, Vol. 28 No. 3, pp. 425-448.

Perkins, Y. (2010), Queensland's Bible in State Schools Referendum 1910: A Case Study of Democracy, Honours, University of Sydney, Sydney.

Queensland. (1865), Industrial and Reformatory Schools Act, available at: http://nla.gov.au/nla.obj54468084 (accessed 12 September 2017).

Queensland. (1906), An Act to Amend the "Industrial and Reformatory Schools Act of 1865", available at: http://www8.austlii.edu.au/cgibin/viewdb/au/legis/qld/hist_act/irsaaao19066evn6578/.

Queensland. (1912), State Education Acts Amendment Act. 
Queensland Legislative Assembly. (1886), "Wednesday 27 October 1886", Parliamentary Debates [Hansard], pp. 1409-1443.

Queensland Legislative Assembly. (1918), "Thursday, 19 September 1918", Parliamentary Debates [Hansard], pp. 2462-2501.

"Queensland State Archives Item ID532416, Register - admissions". (1871), , Queensland State Archives, available at:

http://www.archivessearch.qld.gov.au/Search/ItemDetails.aspx?ltemld=532416.

Queensland Times, Ipswich Herald and General Advertiser. (1865a), "Legislative Assembly. Thursday, June 1", Ipswich, Queensland, 3 June.

Queensland Times, Ipswich Herald and General Advertiser. (1865b), "Legislative Assembly. Thursday, June 1", Ipswich, 3 June.

Quinn, P. (2002), "The 'penal reformatory' that never was: proposals to establish Borstal training in New South Wales, 1900-1948", Journal of the Royal Australian Historical Society, Vol. 88 No. 2, pp. 115-136.

Ramsland, J. (1982), "Henry Parkes and the Development of Industrial and Reformatory Schools in Colonial New South Wales", Australian Social Work, Vol. 35 No. 4, pp. 3-10.

"Report by the Public Service Inspector on the Westbrook Reformatory". (1906), , 1 June.

Richmond, W. (1906), Report of the Superintendent of the Westbrook Reformatory School for Boys, for the Period 1900-5 to the Home Secretary, Brisbane, Home Secretary's Office, Queensland, Westbrook, Queensland.

Richmond, W. (1910), "General Report on the Conditions and Progress of the Westbrook Reformatory for Boys", 16 September.

Richmond, W. (1915), "Superintendent, Westbrook Reformatory for Boys to The Director, State Children Department, Brisbane", 20 February.

Robinson, S. and Wilson, E. (2008), "Preserving the Traditions of a 'great race': youth and national character in Queensland, 1859-1918", Journal of the Royal Australian Historical Society, Vol. 94 No. 2, pp. 166-185.

Ryder, W. (1910), Report of the Under Secretary, Home Secretary's Department, Upon the Industrial and Reformatory Schools Established in Queensland, Queensland Parliament, Brisbane.

Savige, A. (1993), "'Naughty' Boys: The Education of Reformatory School Boys at Lytton 1881-1899", Journal of the Royal Historical Society of Queensland, Vol. 15 No. 1, pp. 33-48.

Schroeder, J. (2008), "SELF-TEACHING: MARY CARPENTER, PUBLIC SPEECH, AND THE DISCIPLINE OF DELINQUENCY", Victorian Literature and Culture, Vol. 36 No. 01, pp. 149-161.

Schwarten, A. (1961), Report: Westbrook Farm Home for Boys Inquiry, Inquiry, Queensland Government, Brisbane.

Scrivener, G. (2000), "Parental imposition or police coercion?: The role of parents and police in committals to the industrial schools in New South Wales, 1867-1905", Journal of the Royal Australian Historical Society, Vol. 86 No. 1, p. 23. 
Sharma, S. (2010), "Contesting institutional discourse to create new possibilities for understanding lived experience: life-stories of young women in detention, rehabilitation, and education", Race Ethnicity and Education, Vol. 13 No. 3, pp. 327-347.

Smith, G.T. (2019), "Muffled Voices: Recovering Children's Voices from England's Social Margins", in Moruzi, K., Musgrove, N. and Pascoe Leahy, C. (Eds.), Children's Voices from the Past, Springer International Publishing, Cham, pp. 263-283.

Stack, J.A. (1979), "The Provision of Reformatory Schools, the Landed Class, and the Myth of the Superiority of Rural Life in Mid-Victorian England", History of Education, Vol. 8 No. 1, pp. 3343.

Stack, J.A. (1994), "Reformatory and industrial schools and the decline of child imprisonment in midVictorian England and Wales", History of Education, Vol. 23 No. 1, pp. 59-73.

Telegraph. (1881), "Queensland News”, Brisbane, 23 November, p. 2.

Telegraph. (1902), "District Court. Criminal Sittings", Brisbane, Qld, 23 January, p. 2.

The Week. (1880), "The Death Sentence at Bowen", Brisbane, 25 December, p. 8.

Thuen, H. (1991), "Education or punishment? Reformatory schools in Norway, 1840-1950", History of Education, Vol. 20 No. 1, pp. 49-60.

Van Krieken, R. (1991), Children and the State: Social Control and the Formation of Australian Child Welfare, Allen \& Unwin, North Sydney.

Vehkalahti, K. (2016), "Dusting the archives of childhood: child welfare records as historical sources", History of Education, Vol. 45 No. 4, pp. 430-445.

Webber, M. (2015), "Honest and Useful?: The Post-Institutional Lives of Refuge for the Destitute Beneficiaries", Journal of Social History, Vol. 48 No. 4, pp. 933-955.

Week. (1883), "Police Court”, Brisbane, Qld, 28 July, p. 11. 